\title{
Production of fermented Omija (Schizandra chinensis) beverage fortified with high content of gamma-amino butyric acid using Lactobacillus plantarum
}

\author{
$\mathrm{Hyo}^{-S e o n} \mathrm{Lee}^{1}$, Soon-Young Kwon ${ }^{1}$, Syng-Ook Lee ${ }^{1}$, Sam-Pin Lee ${ }^{1,2 *}$ \\ ${ }^{1}$ Department of Food and Science and Technology, Keimyung University, Daegu 42601, Korea \\ ${ }^{2}$ The Center for Traditional Microorganism Resource (TMR), Keimyung University, Daegu 42601, Korea
}

\section{오미자(Schizandra chinensis) 열매 추출물의 Lactobacillus plantarum 젖산발효를 통한 고농도 GABA 함유 발효음료 제조}

\author{
이효선 ${ }^{1} \cdot$ 권순영 $^{1} \cdot$ 이승욱 $^{1} \cdot$ 이삼빈 ${ }^{1,2 *}$ \\ ${ }^{1}$ 계명대학교 식품가공학과, \\ ${ }^{2}$ 계명대학교 전통미생물자원개발 및 산업화지원센터
}

\begin{abstract}
Omija (Schizandra chinensis) extract (OE) was fermented by using Lactobacillus plantarum EJ2014 to produce a beverage fortified with gamma-aminobutyric acid (GABA). After 2 days of fermentation in the presence of $2 \%$ monosodium glutamate (MSG) and $0.5 \%$ yeast extract (YE), the four-fold-diluted OE showed a higher viable cell count $\left(2.2 \times 10^{9} \mathrm{CFU} / \mathrm{mL}\right)$ and lower acidity $(1.2 \%)$ than that of the unfermented OE. In particular, addition of MSG as a precursor resulted in a small increase in the initial $\mathrm{pH}$. MSG (2\%) was completely converted to GABA $(0.92 \%)$ during lactic acid bacteria fermentation for 3 days. Furthermore, the acidity of the fermented OE decreased from $1.74 \%$ to $0.56 \%$. In addition, the original red color of the $\mathrm{OE}$ disappeared during LAB fermentation. However, when the fermented $\mathrm{OE}$ was mixed with $50 \%$ of the original $\mathrm{OE}$, the original red color was recovered, with 19.56 and 13.92 for Hunter $L$ and a values, respectively. The mixture of $50 \%$ original $\mathrm{OE}$ and $50 \%$ fermented $\mathrm{OE}$ showed the highest sensory score including the highest overall preference. In conclusion, the OE fortified with GABA and probiotics was produced by fermentation with a static culture, L. plantarum EJ2014.
\end{abstract}

Key words : Omija, GABA, color values, probiotics, yeast extract

\section{서 론}

오미자(Schizandra chinensis Baillon)는 목련과(Magnoliaece) 에 속하며 열매는 5 가지 맛을 가지는 대표적인 한방소재로 서 다양한 가공식품의 원료로 이용되고 있다. 오미자 열매 는 고유한 맛 성분이외에 안토시아닌 색소를 함유하고 있어

*Corresponding author. E-mail : splee@kmu.ac.kr Phone : 82-53-580-5554, Fax : 82-53-580-5729

Received 26 January 2016; Revised 15 March 2016; Accepted 25 March 2016.

Copyright (c) The Korean Society of Food Preservation. All rights reserved.
기호성과 기능성을 제공하는 과실이다(1). 과실의 대표적 인 phytochemical인 안토시아닌은 cyanidin계의 고유한 색 으로 수용성 식용색소로 이용가능성이 높지만, 다른 색소 성분에 비해 가공 공정 중에 불안정한 것으로 알려져 있다 (2). 특히, 안토시아닌 색소의 안정성은 $\mathrm{pH}$, 온도, 빛, 효소, 산소, 당류, 유기산, 금속이온 등의 존재여부에 의해 영향을 받는 것을 보고되었다(3-6). 오미자 열매는 유기산 함량이 매우 높은 과실로서 천연 발효에 어려움이 있어, 오미자 열매를 알코올로 침출 또는 오미자 열매를 당절임에 의한 추출차로서 널리 이용되어 왔다. 오미자 열매 추출액의 첨 가에 따른 요구르트 스타터 증식에 관한 연구(7), 오미자 열매 추출액을 이용한 김치 젖산균의 발효 및 생리활성에 
관한 연구 보고(8)가 있지만 오미자 열매 추출액의 기능성 강화에 관한 발효연구는 전무한 실정이며, 오미자 열매 추 출물의 혈당 강하 작용, 간 기능의 개선에 대한 생리활성 연구가 보고되었다 $(9,10)$.

젖산균은 요구르트, 김치 등 발효제품에 주로 이용되어 왔으며, 최근 probiotics로서 다양한 기능성이 밝혀지면서 젖산균을 응용한 발효 식품이 건강식품으로서 각광을 받고 있다 $(11,12)$. 젖산균이 대장 내에서 혐기성 세균, 포자형성 세균 및 독소생성 세균들의 증식을 억제하기 때문에 장내 균총 개선 및 장수에 중요한 역할을 한다는 사실이 보고되 었다(13). 젖산균의 발효를 통해서 생산되는 젖산 등의 대사 산물은 식품의 외형, 풍미, 맛, 조직감 등을 향상시키며(14), 식품의 저장성 향상을 통해 제품의 안정성을 부여해준다 (15). 현재 대부분의 probiotic제품은 요구르트와 같은 우유 발효제품이며, 최근 Lactobacillus acidophilus, Lactobacillus plantarum 등을 이용하여 자두, 복숭아, 복분자, 당근 등을 이용한 probiotic 과채음료에 관한 연구가 보고되었다(16).

§-Aminobutyric acid(GABA)는 자연계에 분포하는 비단 백질 아미노산의 일종으로 동물의 뇌나 척수에 존재하는 신경전달 물질이다(17). 특히 미생물에 의한 $\mathrm{GABA}$ 의 생성 기작은 세포 내막에서 glutamic acid가 glutamate decarboxylase $(\mathrm{GAD})$ 의 효소에 의하여 탈탄산 반응에 의해서 이루어진다. $\mathrm{GABA}$ 의 대사는 에너지를 생산하고 TCA 회로에서 산화를 위한 탄소의 제공, 질소 저장화합물 및 아미노산 대사산물 등의 여러 가지 기능이 알려져 있다(18). 또한 GABA는 치매예방, 면역 및 기억력증진, 불면 등에 효과가 있는 것으 로 보고되었다 $(19,20)$. 자연계에서 $\mathrm{GABA}$ 는 발아 쌀 녹차, 현미 등에 미량 포함되어 있지만, 최근 다양한 미생물에 의해 GABA생산을 증진시키기 위한 연구가 수행되었다 (19). 따라서 오미자 열매의 고유한 영양 및 기능성 성분에 기능성 $\mathrm{GABA}$ 성분이 강화된 식품소재의 개발은 농산물의 부가가치화를 통해 산업적으로 의미 있는 연구라 사료된 다. 본 연구에서는 건강 식품소재로서 널리 이용되는 오미 자 열매의 고부가가치화를 위해서 유용 식물성 젖산균의 발효를 최적화함으로서 고농도 GABA 및 probiotics를 함유 한 기능성 오미자 발효음료를 제조하는 기본 연구를 수행하 였다.

\section{재료 및 방법}

재 료

오미자 열매는 2015년에 경북 문경에서 생산된 원료를 $-20^{\circ} \mathrm{C}$ 에서 보관한 후 발효할 때 마다 해동하고 착즙한 후 사용하였다. $\gamma$-Aminobutyric acid(GABA) 및 sodium L-glutamate(MSG)는 Yakuri pure chemicals Co., LTD. (Kyoto, Japan)의 제품을 사용하였으며, 생육 촉진제로서 yeast extract(YE)는 조흥(주)(Kyunggido, Korea) 제품을 사 용하였다. 시료 분석에는 특급 시약들을 사용하였다.

\section{균주 분리 및 동정}

$\mathrm{GABA}$ 생성이 우수한 젖산균 분리를 위하여 미강으로부 터 시료 $2 \mathrm{~g}$ 을 멸균 증류수 $18 \mathrm{~mL}$ 에 혼합한 후 $10^{3}$ 배까지 희석하고 Difco ${ }^{\mathrm{TM}}$ Lactobacilli MRS broth agar(Becton, Dickinson and Company, Sparks, MD, USA)에 도말하여 $30^{\circ} \mathrm{C}$ 항온배양기(IS-971R, Jeio Tech. Kimpo, Korea)에서 24 시간 배양하여 균주를 순수 분리하였다. 선별된 젖산균 은 MRS agar plate에서 도말하여 24시간 배양한 후 형태학 적 특성을 비교하였으며, Analytical Profile Index(API) 50 $\mathrm{CHL}$ kit와 $16 \mathrm{~S} \mathrm{rDNA}$ sequencing을 통하여 분류학적 및 유전학적 특성을 동정하였다.

\section{스타터 배양}

젖산균 Lactobacillus plantarum EJ2014 균주를 MRS broth agar 배지에 도말하여 $30^{\circ} \mathrm{C}$ 항온배양기(IS-971S, Jeio Tech. Kimpo, Korea)에서 24시간 배양한 뒤 균주의 단일콜 로니를 취하여 2 회 계대배양한 후, $121^{\circ} \mathrm{C}$ 에서 15 분간 멸균 한 MRS broth에 순수 분리된 L. plantarum EJ2014를 한 백금이 접종하여 $30^{\circ} \mathrm{C}$ 에서 24 시간 정치 배양하여 스타터로 사용하였다. 생균수는 발효물 $1 \mathrm{~g}$ 에 멸균수 $9 \mathrm{~mL}$ 을 첨가하 여 $10^{4}, 10^{5}, 10^{6}$ 배로 단계별로 희석하여 MRS broth agar 배지에 $20 \mu \mathrm{L}$ 도말한 후, $30^{\circ} \mathrm{C}$ 항온배양기에서 24 시간 배양 한 후의 생균수를 colony forming unit $(\mathrm{CFU} / \mathrm{mL})$ 로 나타내 었다.

\section{오미자 열매 추출액의 젖산발효}

냉동 보관된 오미자 열매를 해동하여 선별 한 후, 녹즙기 (NNJ-630JMC, NUC.CO, Daegu, Korea)로 착즙하여 얻어진 주스와 부산물을 모두 혼합한 후 3 배 부피의 $100^{\circ} \mathrm{C}$ 의 열수 를 첨가하여 오미자 열매 착즙액을 제조하였다. 여기에 $\mathrm{GABA}$ 의 전구물질인 $\mathrm{MSG}$ 를 $2 \%$ 동일하게 첨가하였으며, 복합 영양성분인 $\mathrm{YE}$ 를 $0.5 \%$ 를 첨가한 후 L. palntarum $\mathrm{EJ} 2014$ starter $1 \%$ 를 첨가하여 $30^{\circ} \mathrm{C}$ 에서 3 일 동안 정치 배양 하여 오미자 열매 추출물의 발효물을 제조하였다.

\section{오미자 열매 추출액 발효물의 이화학적 분석}

$\mathrm{pH}$ 는 $\mathrm{pH}$ meter(Digital $\mathrm{pH}$ meter $420 \mathrm{~A}+$, Thermo Orion. Beverly, MA, USA)를 이용하여 측정하였다. 발효물 $10 \mathrm{~mL}$ 을 취하여 $\mathrm{pH}$ 를 측정한 후 $0.1 \mathrm{~N} \mathrm{NaOH}$ 로 적정하여 $\mathrm{pH}$ 가 8.3 에 도달할 때 까지 소비된 양을 lactic acid 함량 $(\%, \mathrm{v} / \mathrm{v})$ 으 로 환산하여 적정산도를 측정하였으며, 환원당 함량은 DNS(dinitrosalicylic acid)법에 의해 측정하였다(21).

당도는 전자당도계 $\left(0-93{ }^{\circ} \mathrm{Brix}\right.$, Pocket refractometer, ATAGO, Tokyo, Japan)를 이용해 배양액의 당도를 측정하 
였다. 고형분 함량은 적외선 수분측정기(Kett Electric Laboratory, FD-720, Kett, Japan)를 이용하여 배양액 $5 \mathrm{~mL}$ 에 함유된 수분을 건조한 후 남아있는 고형분의 무게를 측정하 여 나타내었다.

오미자 발효액의 색도는 시료 $2 \mathrm{~g}$ 을 screw cap test tube의 cap(Pyrex, diameter $13 \mathrm{~mm}$ )에 담아 colorimeter(Color reader CR-10, MINOLTA, Osaka, Japan)을 이용하여 L(lightness), $\mathrm{a}$ (redness), b(yellowness) 값을 측정하였다.

\section{GABA생산 및 분석}

$\mathrm{MRS}$ 배지에 $2 \% \mathrm{MSG}$ 를 첨가한 후 $1 \%$ 스타터를 접종하 여 $30^{\circ} \mathrm{C}$ 에서 3 일 동안 정치 배양하여 젖산균에 의한 $\mathrm{GABA}$ 생성을 비교하였다. GABA분석을 위해서 표준물질로서 $\mathrm{MSG}$ 와 $\mathrm{GABA}$ 는 $0.25 \sim 1 \%$ 를 사용하였다, 전개용매는 n-butyl alcohol:acetic acid glacial:water를 3:1:1의 비율로 혼 합하여 실온에서 4시간 이상 포화시켰다. 시료를 $1,500 \mathrm{rpm}$ 에서 10 분간 원심분리한 상등액 원액을 TLC plate의 하단부 에서 $2 \mu \mathrm{L}$ 를 점적한 후 건조시켰다. 밀폐된 유리용기에서 전개시킨 TLC plate는 건조시킨 후 발색시약 $0.2 \%$ ninhydrin을 뿌리고, $100^{\circ} \mathrm{C}$ oven에서 5 분 동안 발색 시킨 후 GABA spot을 확인하였다.

GABA 전환율을 확인하기 위한 유리 아미노산 함량 측정 은 건조시킨 시료를 phenylisothiocyanate(PITC)용액 $20 \mu$ $\mathrm{L}(\mathrm{MeOH}: \mathrm{H} 2 \mathrm{O}: \mathrm{TEA}: \mathrm{PITC}=7: 1: 1: 1)$ 를 유도체화 시킨 뒤 상 온에서 30 분간 반응 시킨다. 시료를 완전히 말린 후 200 $\mu \mathrm{L}$ 의 A solvent로 녹이고 원심분리 시킨 후 상등액을 0.45 $\mu \mathrm{m}$ syringe filter로 여과한 후 HPLC로 분석하였다. 아미노 산 분석은 HPLC 장치(Hewlett Packard 1100 Series, Palo Alto, CA, USA)에 $\mathrm{C}_{18}$ column(Waters Nova-Pak 4 um)을 장착한 후 mobile 용매는 각각 $\mathrm{A}(140 \mathrm{mM} \mathrm{NaHAc}, 0.1 \%$ triethanolamine, $6 \% \mathrm{CH}_{3} \mathrm{CN}, \mathrm{pH}$ 6.1) $100 \%$ 로 elution 후 25 분 동안 $\mathrm{B}\left(60 \% \mathrm{CH}_{3} \mathrm{CN}\right) 100 \%$ 가 되도록 혼합하면서 분당 1 $\mathrm{mL}$ 로 흘려주었다. 아미노산 측정은 $254 \mathrm{~nm}$ 에서 $\mathrm{UV}$ 흡광 도를 측정하였다.

\section{관능검사 및 통계분석}

오미자 젖산 발효물을 $7,000 \mathrm{rpm}$ 에서 20 분간 원심분리한

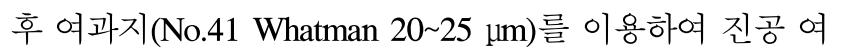
과 후, 병에 나누어 담아 $70^{\circ} \mathrm{C}$ 에서 30 분간 살균시켰다. 발효 음료 시제품은 $4^{\circ} \mathrm{C}$ 에서 24 시간 보관한 다음 계명대학교 식품가공학과 교수, 전공 학생 및 연구원에게 필요한 훈련 과정을 거치게 한 후 신뢰성과 실험에 대한 관심도 등을 고려하여 24명을 관능요원으로 선발하여 실시하였으며 색 (color), 맛(taste), 향(flavor), 발효취 강도(fermented smell intensity), 전반적인 기호도(overall acceptability)에 대하여 7점 채점법으로, 7점 매우 좋다, 1점 매우 나쁘다 로 평가하 였다. 이 때 발효하지 않은 오미자 추출 원액에 $\mathrm{GABA}$ 를
함유한 오미자 발효액을 각 $0,50,75,100 \%$ 의 농도가 되도 록 혼합한 음료 4 가지를 비교하였다. 시료는 흰 바탕의 종이 컵을 이용하여 $30 \mathrm{~mL}$ 을 넣어 검사원에게 제시되었고, 관능 검사 결과 값은 평균과 표준편자로 표시하였으며, 유의성 검정은 SPSS 22.0(SPSS Inc., Chicago, IL, USA) 통계 프로 그램을 이용하여 분산분석(ANOVA test)을 실시하고, Duncan의 다중검정 (Duncan's multiple range test)을 통해 95\% 신뢰 수준에서 나타내었다.

\section{결과 및 고찰}

오미자 열매 추출액의 일반성분

오미자 추출액의 4 배 희석액은 $\mathrm{pH} \mathrm{3.2,} \mathrm{산도} 1.8 \%$, 수용 성 고형분 함량 $2.5{ }^{\circ} \mathrm{Brix}$ 및 환원당 $0.87 \%$ 를 나타내었다. 오미자 추출액은 고유한 적색을 보이면서 초기 색도 $\mathrm{L}$, $\mathrm{a}, \mathrm{b}$ 값은 각각 $26.43,25.41,15.60$ 으로 나타내었다. 최근 오미자 열매 추출액의 젖산균 발효연구에서 오미자 추출액 은 $\mathrm{pH} 3.0$ 이하로 낮은 값을 나타내었으며, $5 \%$ 수준으로 희석시킨 초기 혼합액의 $\mathrm{pH}$ 는 4.5 이상으로 증가되었다고 보고하였다(8). 또한 오미자 열매의 3시간 동안 열수 추출 시 $\mathrm{pH} 3.1$ 및 산도 $2.42 \%$ 를 나타냄을 보고하였다(7). 다른 과실류에 비해서 오미자의 열매 추출액의 초기 $\mathrm{pH}$ 는 존재 하는 유기산에 의해서 매우 낮음을 알 수 있었다.

\section{균주의 선별 및 동정}

미강에서 선별된 GABA 생성능이 우수한 균주는 $\mathrm{API}$ CHL kit로 분석한 결과 sucrose, maltose, lactose, raffinose, trehalose 등을 탄소원으로 이용하는 Lactobacillus plantarum 으로 분류되었으며, $16 \mathrm{~S}$ rDNA sequencing으로 동정한 결과 L. plantarum에 $99.9 \%$ 상동성을 갖는 것으로 나타났다. 분 리 균주는 한국미생물보존센터에 L. plantarum EJ2014 (KCCM 11545P)로 국제특허기탁을 하였다. GABA 생성능 이 우수한 균주로 알려진 Lactobacillus plantarum K154 (KACC 91727P)와 MRS agar plate에서 배양된 형태를 비교 하였을 때 L. plantarum EJ2014는 colony 크기가 작으면서 미색보다는 흰색을 나타내었다(data not shown). Fig. 1에서 처럼 젖산균의 MRS 배양액에서 GABA 생성능을 TLC를 이용하여 분석한 결과 L. plantarum $\mathrm{EJ} 2014$ 이 L. plantarum $\mathrm{K} 154$ 보다 GABA 생성능이 우수한 균주로 판단되어 본 연구에서 $\mathrm{GABA}$ 생산 균주로 사용하였다.

\section{오미자 열매 추출액의 젖산발효 최적화}

오미자 열매 추출액은 높은 산도와 다양한 phytochemical 이 함유되어 있어서 미생물의 생육억제를 통한 발효식품의 저장성을 높이는데 관여하는 것을 보고되었다(22). 오미자 열매 추출액의 첨가에 따른 김치 젖산발효를 수행할 때 


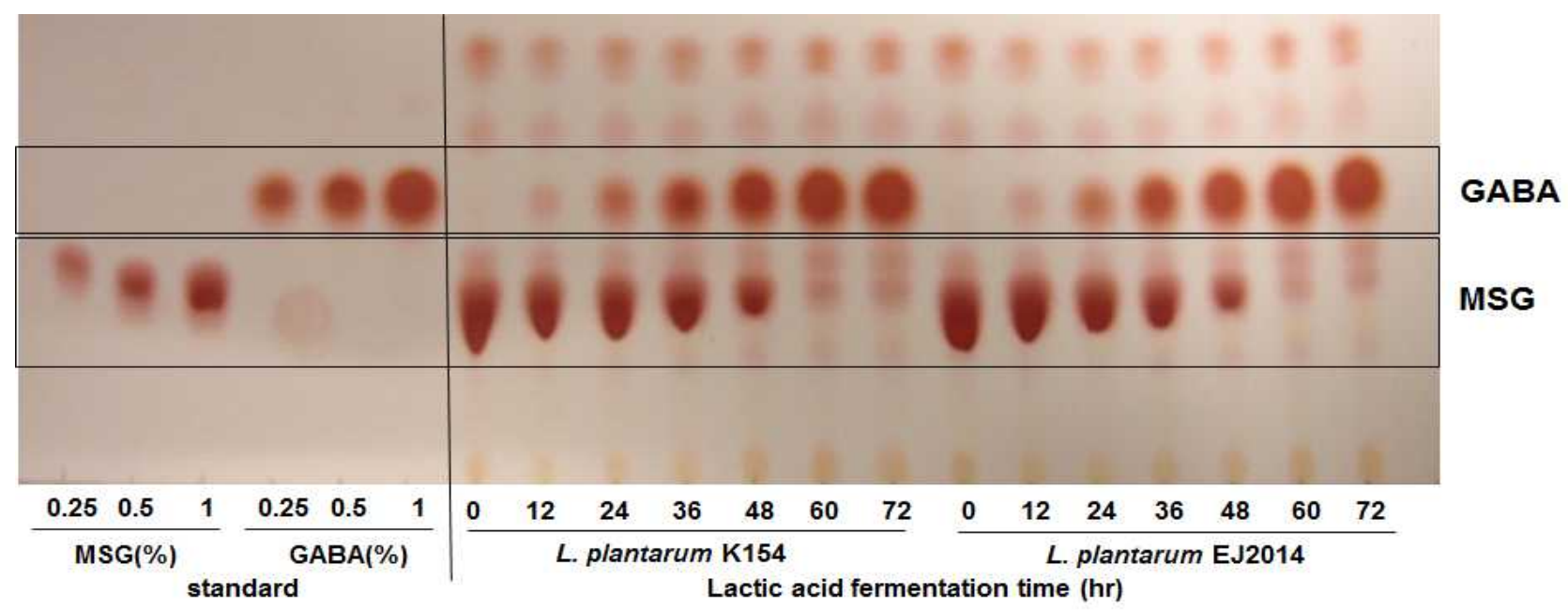

Fig. 1. TLC patterns of GABA obtained from the Lactobacilli MRS broth during lactic acid fermentation by L. plantarum K154 and L. plantarum EJ 2014.

젖산균의 생육억제가 수반되었으며, 이는 오미자 열매 추 출물이 함유한 정유성분에 의한 것으로 보고되었다(23). 최근 오미자 열매 추출액의 젖산 발효에서 $\mathrm{pH} 3$ 정도의 낮은 값을 보이는 추출액은 발효시간에 따른 $\mathrm{pH}$ 변화가 없어 균의 생육이 일어나지 않은 것을 보고하였다(8). 오미 자 열매 추출액을 이용하여 효과적인 젖산발효를 위한 예비 실험에서 오미자 열매 추출액의 희석에 따른 발효조건의 최적화를 수행하였다. 이때 오미자 열매 추출액을 4 배 희석 한 경우 젖산 발효 3 일째까지 생균수 $1.4 \times 10^{9} \mathrm{CFU} / \mathrm{mL}$ 로 가장 높게 유지되고, 적정산도가 $2.81 \%$ 로 증가되는 것을 확인하였다(data not shown). 따라서 오미자 열매 추출액의 효과적인 젖산발효를 위해서는 추출액의 희석이 필요하며, 본 실험에서는 4 배 희석한 오미자 열매 추출액을 이용하여 GABA생산을 위한 젖산발효를 수행하였다.

오미자 열매 추출액의 질소원 첨가에 따라 젖산균 생육 의 최적화를 위해서 복합 영양성분인 $\mathrm{YE}$ 를 농도별로 첨가 하여 젖산균의 생균수를 확인하였다. $\mathrm{YE}$ 무첨가 군에서 초기 생균수 $3.0 \times 10^{7} \mathrm{CFU} / \mathrm{mL}$ 에서 발효 3일 동안 $6.4 \times 10^{8}$ $\mathrm{CFU} / \mathrm{mL}$ 으로 낮은 값을 나타내었다. 반면에 $\mathrm{YE} 0.1 \%$ 이상 의 농도 첨가군에서 젖산 발효 1 일째부터 생균수는 $1.5 \times 10^{9}$ $\mathrm{CFU} / \mathrm{mL}$ 이상으로 증가하였다(data not shown). 따라서 오 미자 열매 추출물의 젖산발효를 위해서 영양성분으로 $0.1 \%$ 이상의 $\mathrm{YE}$ 첨가는 생균수를 높이면서 젖산발효가 효과적 으로 진행되는 것으로 확인하였다.

생균수, $\mathrm{pH}$, 산도 및 색도 변화

오미자 열매 추출물을 이용하여 젖산발효를 통한 GABA 생성을 최적화하기 위해서 영양성분과 질소원으로 $\mathrm{YE}$ 와 $\mathrm{MSG}$ 의 첨가효과를 비교하였다. 오미자 열매 추출액의 젖 산발효를 수행하면서 $\mathrm{YE}$ 의 첨가는 젖산균의 생균수를 높 이는 데 크게 기여하였으며, 선행연구에서 $\mathrm{YE} 0.5 \%$ 첨가
시 당도가 크게 감소하면서 젖산발효가 효과적으로 수행됨 을 확인할 수 있었다. 최근 오미자 열매 추출액 $5 \%$ 희석액의 젖산발효를 수행하면서 $3 \%$ 수준의 $\mathrm{YE}$ 를 포함하여 다양한 무기질과 당을 첨가한 후 젖산발효를 수행한 연구결과가 보고되었다(8).

본 실험에서는 적정 농도의 $\mathrm{YE}$ 첨가 조건에서 젖산발효 를 수행하기 위해 오미자 열매 추출액에 $\mathrm{YE} 0.5 \%, \mathrm{MSG}$ 농 도를 $0,2 \%$ 수준으로 첨가 유무에 따라 3 일 동안 젖산 발효 를 수행하면서 생균수 및 GABA 생성을 비교하였다. 생균 수를 측정한 Table 1에서 발효 전 모든 군에서 젖산균 생균 수는 $3.0 \times 10^{7} \mathrm{CFU} / \mathrm{mL}$ 이었으며, $\mathrm{MSG}$ 만 첨가한 군에서는 1 일 째 $4.4 \times 10^{8} \mathrm{CFU} / \mathrm{mL}$ 로 증가하여 3일째 까지 생균수가 유지되었고, $\mathrm{YE}$ 첨가군은 2 일 발효 후 $5.9 \times 10^{8} \mathrm{CFU} / \mathrm{mL}$ 으 로 증가하여 3 일째까지 유지되었다. $\mathrm{GABA}$ 생성의 전구물 질로서 $\mathrm{MSG}$ 와 함께 $\mathrm{YE}$ 를 첨가한 군에서는 1 일 부터 $1.5 \times 10^{9} \mathrm{CFU} / \mathrm{mL}$ 으로 생균수가 급격하게 증가하여 3일째 까지 유지되는 것을 알 수 있었다. 이로서 오미자 열매 추출 액에 MSG와 $\mathrm{YE}$ 를 함께 첨가함으로써 젖산균의 생육과

Table 1. Changes in the viable cell counts of the Schizandra chinensis extract during lactic acid fermentation by $L$. plantarum EJ2014 in the presence of YE and MSG

(CFU/mL)

\begin{tabular}{ccccc}
\hline \multirow{2}{*}{ Group } & \multicolumn{4}{c}{ Viable cell count } \\
\cline { 2 - 5 } & \multicolumn{4}{c}{ Fermentation time (days) } \\
\cline { 2 - 5 } & 0 & 1 & 2 & 3 \\
\hline Control & $3.0 \times 10^{7}$ & $2.8 \times 10^{7}$ & $4.0 \times 10^{7}$ & $8.1 \times 10^{8}$ \\
MSG & $3.0 \times 10^{7}$ & $4.4 \times 10^{8}$ & $8.3 \times 10^{8}$ & $6.4 \times 10^{8}$ \\
YE & $3.0 \times 10^{7}$ & $2.0 \times 10^{7}$ & $5.9 \times 10^{8}$ & $4.2 \times 10^{8}$ \\
$\mathrm{M}+\mathrm{Y}^{1)}$ & $3.0 \times 10^{7}$ & $1.5 \times 10^{9}$ & $2.2 \times 10^{9}$ & $1.4 \times 10^{9}$ \\
\hline
\end{tabular}

${ }^{15} \mathrm{M}+\mathrm{Y}$, omija extract fortified with $2 \% \mathrm{MSG}$ and $0.5 \%$ YE. 
생균수 유지에 효과적인 것으로 나타났다. 오미자 열매 착 즙액을 4 배 희석한 후 영양성분으로 소량의 $\mathrm{YE}$ 를 첨가하여 성 공적으로 젖산발효를 수행할 수 있었으며, 특히 질소원 으로 $\mathrm{MSG}$ 를 첨가함으로서 젖산발효를 통해서 $\mathrm{GABA}$ 와 같은 유용한 대사산물을 생산할 수 있는 최적 환경을 조성 할 수 있었다.

오미자 열매 추출액의 젖산발효 과정 중에 $\mathrm{pH}$ 와 적정산 도를 측정한 결과는 Fig. 2에 나타내었다. 오미자 추출액은 적색의 안토시안 색소를 함유하고 있어서 관능적으로 매우 중요한 기호성을 나타내며, 색소의 안정성은 $\mathrm{pH}$ 에 크게 의존한다. 본 실험에서 $2 \%$ 수준으로 MSG 첨가는 발효 후에 오미자 열매 추출물의 고유한 적색이 옅어지는 것을 확인할 수 있었다.

색도의 변화를 관찰한 Table 2에서 YE $0.5 \%$ 만 첨가한 조건에서는 적색도와 황색도가 발효 3일까지 감소하는 것 으로 나타났다. 반면에 $\mathrm{MSG}$ 와 $\mathrm{YE}$ 함께 첨가한 발효조건에 서는 젖산발효 1 일째부터 발효물의 붉은 색이 퇴색되면서 황색으로 변화하였다. 발효 중에 고유한 적색의 변화를 Hunter 색도계로 색도를 측정하였을 때, 대조군인 오미자 열매 추출액은 3 일째까지 색도 값의 변화가 없었다. 반면에 $\mathrm{MSG}$ 만 2\% 첨가한 조건에서는 발효가 진행됨에 따라 적색 이 약해지면서 a값이 18.24 에서 8.61로 크게 감소하는 것으 로 나타났으며, b값 또한 6.15 에서 4.04 로 감소하였다. 특히, $\mathrm{MSG}$ 와 $\mathrm{YE}$ 함께 첨가한 발효조건에서도 발효 초기에 적색 이 일부 감소하면서 a값이 15.74 를 나타내었으며, 발효 3 일 후에 5.39로 크게 감소하고, $\mathrm{b}$ 값은 발효 초기 7.85 에서 6.28 로 감소하는 것으로 나타났다. 그러나 $\mathrm{YE}$ 만의 첨가는 오미 자 추출액의 고유한 색상의 변화가 다른 발효 조건에 비해 서 적은 것으로 나타났다.

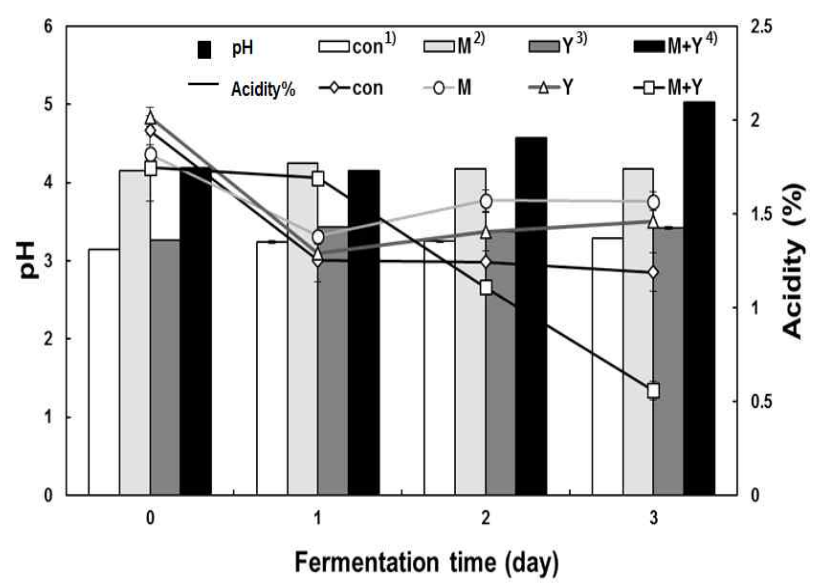

Fig. 2. Changes in the $\mathrm{pH}$ and acidity of the Schizandra chinensis extract during lactic acid fermentation by L. plantarum EJ 2014 in the presence of YE and MSG.

\footnotetext{
${ }^{1)}$ Omija extract was fermented by $L$ plantarum EJ2014.

${ }^{2)}$ Omija extract was fortified with $2 \%$ MSG.

${ }^{3)}$ Omija extract was fortified with $0.5 \%$ YE.

${ }^{4}$ Omija extract was fortified with $2 \%$ MSG and $0.5 \%$ YE
}

발효 전 MSG만 첨가하여도 오미자 열매 추출액의 초기 $\mathrm{pH}$ 가 3.14에서 4.16으로 증가하였다. 이는 중성의 아미노산 인 $\mathrm{MSG}$ 를 첨가함으로써 산성의 오미자 추출액의 $\mathrm{pH}$ 가 일부 증가하면서 알칼리 쪽 $\mathrm{pH}$ 변화에 따라 안토시아닌 색소에 영향을 주는 것으로 판단되었다. 젖산균에 의한 발 효가 진행됨에 따라 대조군의 $\mathrm{pH}$ 는 3.14에서 $\mathrm{pH} 3.30$ 까지 증가하고 적정산도는 $1.94 \%$ 에서 $1.19 \%$ 까지 감소하는 것을 볼 수 있었다. 특히 GABA 생산의 전구물질인 $\mathrm{MSG}$ 를 $\mathrm{YE}$ 와 함께 첨가하였을 때는 초기 $\mathrm{pH}$ 4.19에서 $\mathrm{pH} 5.03$ 으로 크게 증가하였고, 적정산도는 발효 초기 $1.74 \%$ 에서 3 일에 $0.56 \%$ 로 적정산도가 급격히 감소하였다. 오미자 열매 추출액이 젖산발효가 수행되면서 초기 산도보다 감소하는 경향을 보이는 것은 일반적인 과실류의 젖산발효 양상과 다른 결과 를 나타내는 것으로, 발효가 진행되면서 산성을 나타내는 유기산의 일부가 소비되는 것으로 사료된다. 특히 젖산발 효에서 $\mathrm{GABA}$ 생산을 위해 첨가되는 전구물질인 $\mathrm{MSG}$ 는 세포내 탈산산효소에 의해서 $\mathrm{GABA}$ 로 전환되면서 발효물 의 산도를 유지 또는 감소시키는 경향을 나타내었다(data not shown).

Table 2. Changes in the color values of the Schizandra chinensis extract during lactic acid fermentation by L. plantarum EJ2014 in the presence of YE and MSG

\begin{tabular}{cccccc}
\hline & Color & \multicolumn{4}{c}{ Fermentation time (days) } \\
\cline { 3 - 6 } & value & 0 & 1 & 2 & 3 \\
\hline \multirow{4}{*}{ Control } & L & $22.24 \pm 0.11$ & $26.71 \pm 0.15$ & $26.13 \pm 0.10$ & $25.86 \pm 0.04$ \\
& a & $22.38 \pm 0.05$ & $23.48 \pm 0.08$ & $23.96 \pm 0.22$ & $22.89 \pm 0.10$ \\
& b & $12.47 \pm 0.19$ & $13.48 \pm 0.26$ & $14.40 \pm 0.02$ & $13.26 \pm 0.05$ \\
\hline \multirow{3}{*}{ MSG } & L & $27.11 \pm 0.10$ & $32.25 \pm 0.04$ & $32.05 \pm 0.07$ & $27.81 \pm 0.05$ \\
& a & $18.24 \pm 0.38$ & $11.16 \pm 0.53$ & $13.09 \pm 1.14$ & $8.61 \pm 0.01$ \\
& b & $6.15 \pm 0.06$ & $3.15 \pm 0.04$ & $3.70 \pm 0.02$ & $4.04 \pm 0.05$ \\
\hline \multirow{3}{*}{ YE } & L & $23.18 \pm 0.07$ & $24.62 \pm 0.08$ & $23.80 \pm 0.01$ & $23.75 \pm 0.17$ \\
& a & $23.05 \pm 0.14$ & $20.33 \pm 0.18$ & $17.73 \pm 0.04$ & $10.54 \pm 0.04$ \\
& b & $13.66 \pm 0.09$ & $12.51 \pm 0.11$ & $9.97 \pm 0.02$ & $4.53 \pm 0.06$ \\
\hline \multirow{3}{*}{ M+Y } & L & $24.96 \pm 0.03$ & $26.26 \pm 0.03$ & $27.31 \pm 0.10$ & $26.71 \pm 0.12$ \\
& a & $15.74 \pm 0.20$ & $7.92 \pm 0.01$ & $5.66 \pm 0.02$ & $5.39 \pm 0.07$ \\
& b & $7.85 \pm 0.07$ & $6.23 \pm 0.03$ & $6.38 \pm 0.04$ & $6.28 \pm 0.06$ \\
\hline
\end{tabular}

$\mathrm{GABA}$ 생산 최적화에 $\mathrm{YE}$ 및 $\mathrm{MSG}$ 첨가 효과

발효성 당이 존재하는 과즙을 이용한 젖산발효에서는 발효중에 젖산의 생성에 의해서 산도가 증가되는 것이 일반 적이다, 특히 정상 젖산발효균인 L. plantarum은 $1 \mathrm{~mole}$ 발효성 당으로부터 $2 \mathrm{~mole}$ 젖산을 생성함으로서 발효물의 산도를 높이는 대표적인 발효미생물이다. 그러나 오미자 열매 추출액의 젖산발효에서는 젖산균의 생육에도 불구하 고 산도가 감소하는 경향을 보이는 것이 매우 이례적인 결과이다. 이는 젖산 발효시에 원료에 존재하는 발효성 당 
의 함량에 따라 산생성에 영향을 미치는 것으로 판단되며, 발효성 당이 부족한 오미자 열매 추출 희석액에서 존재하는 유기산이 탄소원으로 이용되는 것으로 사료되었다. 우유 또는 과실류에 존재하는 구연산이 젖산균에 의해서 발효성 과 함께 이용되며, 궁극적으로 대사 과정중에 diacetyl, acetoin으로 전환될 수 있다고 보고하였다(24). 동일한 오미 자 열매 추출 희석액을 젖산 발효시킬 때에 추가적으로 $5 \%$ 설탕을 첨가한 경우에서는 초기 산도가 $2.1 \%$ 에서 발효 3 일에 $3.4 \%$ 로 산도가 증가하는 경향을 보인 선행 연구결과 를 근거로 젖산 발효시에도 발효성 당의 부족은 산도 감소 를 초래할 수 있다고 사료되었다. 미나리 열수 추출액에서 동일한 젖산균에 의한 고농도 $\mathrm{GABA}$ 가 생성될 경우에 발효 액의 산도가 감소하는 경향을 보였다(data not shown), 최근 미생물에 의한 GABA생산은 산성화 스트레스에 대한 방어 수단으로 glutamate로부터 GABA 생산과정의 효소적 반응 에서 세포내 proton이 소비되는 것으로 보고되었다(25). 따

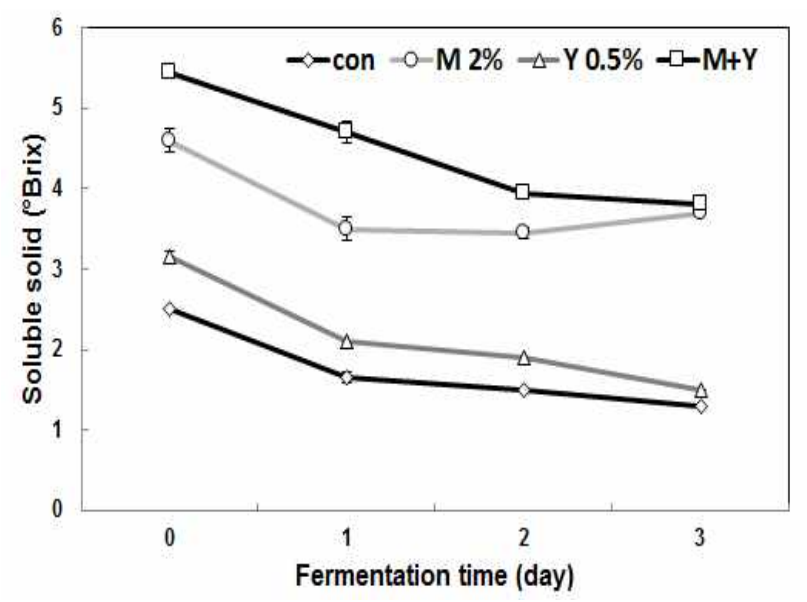

Fig. 3. Changes in the soluble solids ( $\left.{ }^{\circ} \mathrm{Brix}\right)$ of the Schizandra chinensis extract during lactic acid fermentation by $L$. plantarum EJ2014 in the presence of YE and MSG.
라서 GABA 생산 젖산균을 이용하여 엽록소가 풍부한 채소 류의 젖산 발효시에 기능성 GABA 함량을 강화시키는 동시 에 산도의 감소에 따라 원료의 클로로필 색소가 산성에서 불안정화 되어 퇴색되는 단점을 보완할 수 생물전환기술로 사료된다. 오미자 열매 추출액의 $\mathrm{YE}$ 또는 $\mathrm{MSG}$ 첨가에 따른 수용성 고형분 함량의 변화를 Fig. 3에 나타낸 바와 같이, 초기 오미자 열매 추출액의 수용성 고형분 함량은 대조군 $2.5{ }^{\circ} \mathrm{Brix}$ 에서 $\mathrm{MSG}$ 첨가에 따라 $4.6^{\circ} \mathrm{Brix}$ 로 증가하 였으며, $\mathrm{MSG}$ 와 $\mathrm{YE}$ 를 함께 첨가한 경우에 $5.5{ }^{\circ} \mathrm{Brix}$ 로 증가 하였다. 대조군과 $\mathrm{YE} 0.5 \%$ 를 첨가한 경우에 발효 3일에 각각 $1.2{ }^{\circ} \mathrm{Brix}, 1.5{ }^{\circ} \mathrm{Brix}$ 로 감소하였으며, MSG $2 \%$ 만 첨가 한 조건에서는 고형분 함량이 발효 1 일에 $3.5^{\circ} \mathrm{Brix}$ 로 감소 한 후 약간 증가하는 경향을 나타내었다. 이는 오미자 추출 액에 추가로 첨가된 $\mathrm{MSG}$ 가 $\mathrm{GABA}$ 로 전환되지 않고 잔존 하는 것에 기인하는 것으로 사료되었다. MSG와 $\mathrm{YE}$ 를 함께 혼합하여 첨가한 조건에서는 발효 3 일에 $3.9{ }^{\circ} \mathrm{Brix}$ 로 감소 하였다. 따라서 오미자 추출액에 존재하는 발효성 당이 젖 산발효 동안에 소비되면서 수용성 고형분 함량이 대조군과 유사한 양상으로 감소하는 것으로 나타났다.

오미자 열매 추출액에 MSG와 YE 첨가 효과에 따라 생성 된 GABA 함량은 Fig. 4에서 나타낸 것처럼 대조군 또는 $2 \% \mathrm{MSG}$ 만 첨가한 조건에서는 전구물질 $\mathrm{MSG}$ 가 $\mathrm{GABA}$ 로 전환이 전혀 이루어지지 않았으며, $\mathrm{YE}$ 만 $0.5 \%$ 를 첨가한 조건에서는 $\mathrm{GABA}$ 로 미량 전환되는 것으로 나타났다. 반면 에 $\mathrm{MSG}$ 와 $\mathrm{YE}$ 를 함께 첨가한 조건에서는 젖산발효 1 일째 부터 $\mathrm{MSG}$ 를 소진하면서 $\mathrm{GABA}$ 로 전환되는 것을 볼 수 있었으며, 3 일째에는 MSG $2 \%$ 를 대부분 소진하는 것으로 나타났다. 오미자 열매 추출액에 $\mathrm{YE}$ 와 $\mathrm{MSG}$ 를 첨가한 후 젖산발효를 3 일 동안 수행하여 얻어진 발효물의 GABA 함량을 HPLC로 정량 분석한 결과를 Table 3에서 나타내었 다. 발효물의 cysteine(Cys), tryptophan(Trp)을 제외한 18개 아미노산을 분석하였으며, 전체 유리 아미노산은 젖산균에

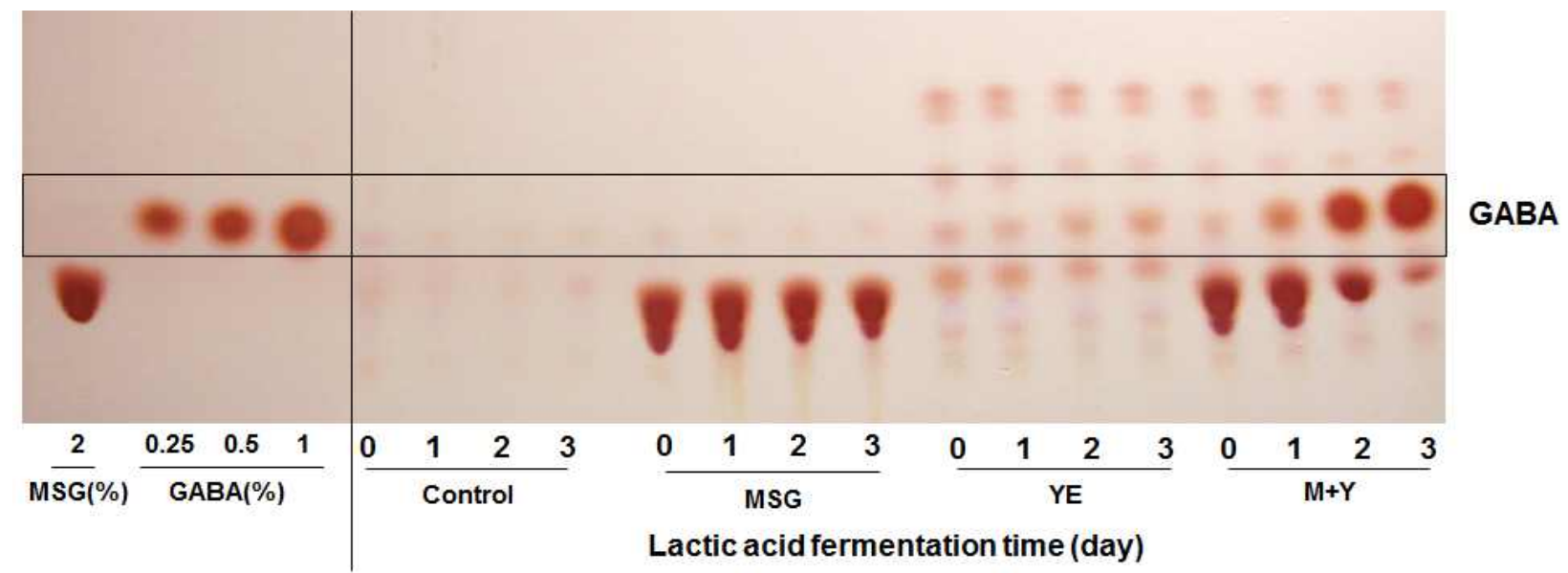

Fig. 4. Changes in the GABA content of the Schizandra chinensis extract during lactic acid fermentation by L. plantarum EJ 2014 in the presence of YE and MSG. 
Table 3. Changes in the free amino acids of the Schizandra chinensis extract fermented by $L$. plantarum EJ2014 in the presence of YE and MSG

$(\mu \mathrm{g} / \mathrm{mL})$

\begin{tabular}{ccc}
\hline & \multicolumn{2}{c}{ Schisandra chinensis extract ${ }^{1)}$} \\
\cline { 2 - 3 } & Before fermentation & After fermentation \\
\hline ASP & 82.67 & 182.69 \\
GLU & $14,267.42$ & $4,362.14$ \\
ASN & 48.97 & 50.88 \\
SER & 81.33 & 4.09 \\
GLN & 62.09 & 91.44 \\
GLY & 47.32 & 60.41 \\
HIS & 23.91 & 20.16 \\
ARG & 120.85 & 122.56 \\
THR & 76.01 & 65.03 \\
ALA & 162.40 & 113.36 \\
GABA & 220.49 & $9,276.38$ \\
PRO & 54.98 & 57.00 \\
TYR & 90.36 & 54.20 \\
VAL & 120.84 & 103.98 \\
MET & 34.43 & 25.60 \\
ILE & 124.03 & 89.63 \\
LEU & 187.52 & 134.91 \\
PHE & 124.78 & 69.33 \\
LYS & 170.98 & 168.48 \\
\hline TOTAL & 16.101 .39 & $15,052.27$ \\
\hline & & \\
\hline
\end{tabular}

${ }^{1)}$ Omija extract was fortified with $0.5 \%$ YE and $2 \%$ MSG.

의해서 생성된 $\mathrm{GABA}$ 를 포함하여 초기 $16.1 \mathrm{mg} / \mathrm{mL}$ 에서 발효 후 $15.0 \mathrm{mg} / \mathrm{mL}$ 로 약간 감소하는 경향을 보였다. 이는 젖산균의 발효 3 일 동안 배양기간에 영양성분으로 아미노 산 일부를 소비한 것으로 사료되었다. 초기 전구물질로 $\mathrm{MSG}$ 는 $14.3 \mathrm{mg} / \mathrm{mL}$ 에서 발효 후에 $4.3 \mathrm{mg} / \mathrm{mL}$ 감소하였으 며, 반면에 GABA 물질은 초기 $0.2 \mathrm{mg} / \mathrm{mL}$ 의 미량에서 9.2 $\mathrm{mg} / \mathrm{mL}$ 로 크게 증가하는 것으로 나타났다.

특히, 오미자 열매 추출액에 발효성 당을 추가적으로 첨 가한 후 젖산발효를 수행하는 경우에 전구물질인 $\mathrm{MSG}$ 로 부터 GABA로 전환은 매우 미비하였으며, 발효 7일에도 대부분의 MSG는 잔존하는 것으로 나타났다(data not shown). 이는 젖산균에 의해서 $\mathrm{GABA}$ 생산을 효과적으로 수행하기 위해서는 배지의 영양성분으로 탄소원과 질소원 의 비율이 중요한 것으로 사료되며, 발효성 당의 제한적인 조건에서 질소원인 $\mathrm{MSG}$ 의 함량이 높을 때 $\mathrm{GABA}$ 전환이 효율적인 것으로 판단되었다.

결론적으로 오미자 열매 추출액의 효과적인 젖산발효를 위해서는 오미자 추출액을 4 배 희석시키는 것이 필요하며,
특히 복합 영양물질인 $\mathrm{YE}$ 의 첨가가 L plantarum EJ2014에 의한 젖산발효를 촉진하여 생균수를 높이는 것으로 나타났 다. 특히 발효성 당이 부족한 오미자 열매 추출 희석액에 질소원으로 $2 \%$ 수준으로 첨가된 $\mathrm{MSG}$ 를 효과적으로 $\mathrm{GABA}$ 로 전환시킴으로서 기능성물질이 강화된 오미자 발 효소재를 제조할 수 있었다. 그러나 젖산 발효된 오미자 열매 추출액의 천연 적색소의 변색에 따라 발효액에 오미자 추출 원액을 농도별로 혼합하여 발효음료를 제조하기 위한 최적 비율을 설정하는 것이 필요하였다.

\section{오미자 젖산 발효음료 제조}

오미자 착즙 원액에 오미자 젖산 발효물을 농도별로 첨 가하여 색과 맛을 보완한 오미자 젖산 발효 음료를 제조하 였다. 오미자 젖산 발효물의 비율을 각각 $0,50,75,100 \%$ 로 첨가하는 4 가지 조건으로 하여 오미자 착즙 원액과 함께 혼합하여 색도를 측정하였다(Table 4, Fig. 5). 오미자 발효 음료 제조 시 오미자 열매 추출액에 발효된 오미자 추출액 의 첨가비율이 높아질수록 적색이 감소하였으며, $50 \%$ 첨가 군에서 L값 19.56 , a값 13.92로 낮은 값을 나타내었다. 하지 만 오미자 젖산 발효물이 더 첨가함으로써 급격히 $\mathrm{b}$ 값이 감소하였으나, 50 100\% 첨가된 조건에서는 b값의 차이가 거의 나타나지 않았다. 최종 발효음료의 색상은 오미자 착 즙 원액과 오미자 젖산 발효물의 농도가 50:50 비율로 혼합 한 조건이 가장 양호한 것으로 나타났다. 이를 통해서 오미 자 열매 추출액은 $\mathrm{GABA}$ 와 probiotics를 함유하며 오미자 고유의 색상을 갖는 오미자 발효음료 제조가 가능하다고 사료되었다.

Table 4. Changes in the color values of the Schizandra chinensis extract mixed with various concentrations of the Shizandra chinenesis extract fermented by L. plantarum EJ2014

\begin{tabular}{ccccc}
\hline \multirow{2}{*}{ Color value } & \multicolumn{4}{c}{ Fermented Schizandra chinenesis concentration $(\%)$} \\
\cline { 2 - 5 } & 0 & 50 & 75 & 100 \\
\hline L & $26.43 \pm 0.07^{1)}$ & $19.56 \pm 0.04$ & $22.22 \pm 0.26$ & $25.42 \pm 0.26$ \\
a & $25.41 \pm 0.04$ & $13.92 \pm 0.09$ & $10.80 \pm 0.21$ & $5.53 \pm 0.30$ \\
b & $15.60 \pm 0.14$ & $3.61 \pm 0.10$ & $3.62 \pm 0.21$ & $4.93 \pm 0.09$ \\
\hline
\end{tabular}

${ }^{1)}$ Values are means \pm SD

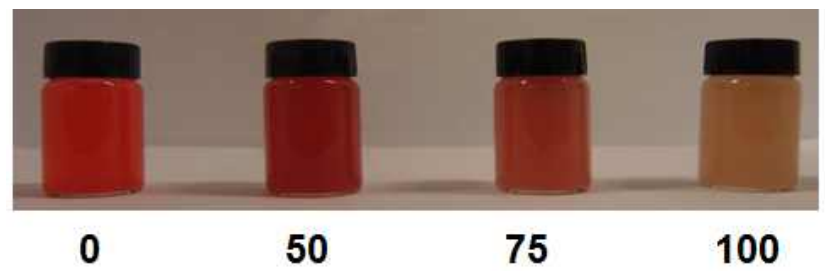

Fig. 5. Changes in the color of the Schizandra chinensis extract mixed with various concentrations of the Schizandra chinenesis extract fermented by $L$. plantarum EJ 2014 . 


\section{관능평가}

발효하지 않은 오미자 착즙 원액에 $\mathrm{GABA}$ 를 함유한 발효 물을 $0,50,75,100 \%$ 비율로 발효물을 혼합한 4 가지 군을 비교하여 관능평가를 실시하였다(Table 5). 계명대학교 식 품가공학과 교수, 전공 학생 및 연구원 24명을 관능요원으 로 선발하여 실시하였으며 색(color), 맛(taste), 향(flavor), 발효취 강도(fermented smell intensity), 전반적인 기호도 (overall acceptability)에 대한 관능검사를 실시한 결과는 Table 5와 같다.

색에 대한 기호도는 오미자 추출액에 발효물을 첨가할수 록 색에 대한 기호도가 감소하는 것으로 나타났으며, 오미 자 젖산 발효물을 $50 \%$ 첨가한 실험군이 6.33점을 획득하여 가장 높은 값을 나타내었다.

오미자 젓산 발효물을 첨가하지 않은 오미자 추출액의 맛은 3.67점을 획득하여 가장 낮은 점수를 나타내었다. 이 는 오미자 추출액에는 오미자 고유의 강한 신맛, 쓴맛 등이 강하여 거부감을 주는 것으로 사료되었다. 하지만 오미자 젖산 발효물을 $50,75 \%$ 첨가 했을 때, 각각 $5.50,6.00$ 점으로 높은 점수를 획득하였다. 이는 오미자 젓산 발효물 첨가가 오미자 추출액이 가지는 고유의 강한 맛을 완화시키며, 발 효 대사산물로 생성된 유기산 등이 오미자 착즙 원액과 조화를 이루면서 맛과 풍미가 증진되어 기호도가 증진된 것으로 생각되었다. 오미자 젖산 발효물은 4.33점으로 낮은 점수를 획득하였으며, 이는 오미자 추출액의 희석액의 젓 산 발효가 진행되면서 오미자 고유의 맛에 비하여 발효에 의해 생성된 유기산 맛과 고형분 함량이 적은 관계로 다른 실험군에 비해 낮은 점수를 나타낸 것으로 사료되었다. 향에서는 오미자 젖산 발효물을 $50 \%$ 첨가한 군이 6.33 으 로 가장 높은 점수를 보였으며, 오미자 젓산 발효물 첨가비 율이 높아질수록 점수가 낮게 나타났다. 이는 오미자 젖산 발효에 의해 생성된 풍미가 강하였기 때문이라 판단되었 다. 이에 따른 전반적인 기호도를 나타낸 관능평가 점수에 서는 발효를 하지 않은 오미자 착즙액과 발효물 $100 \%$ 함유

Table 5. Sensory evaluation scores of the Schizandra chinensis extract fortified with various concentrations of the Schizandra chinenesis extract fermented by L. plantarum EJ2014

\begin{tabular}{ccccc}
\hline \multirow{2}{*}{$\begin{array}{c}\text { Sensory } \\
\text { characteristics }\end{array}$} & \multicolumn{4}{c}{ Fermented Schizandra chinenesis content (\%) } \\
\cline { 2 - 5 } & 0 & 50 & 75 & 100 \\
\hline Color & $6.00 \pm 0.63^{1 \mathrm{lc} 2)}$ & $6.33 \pm 0.52^{\mathrm{c}}$ & $5.00 \pm 0.63^{\mathrm{b}}$ & $4.17 \pm 0.41^{\mathrm{a}}$ \\
Taste & $3.67 \pm 0.82^{\mathrm{a}}$ & $5.50 \pm 0.84^{\mathrm{b}}$ & $6.00 \pm 0.63^{\mathrm{b}}$ & $4.33 \pm 0.82^{\mathrm{ab}}$ \\
Flavor & $5.33 \pm 0.52^{\mathrm{a}}$ & $6.33 \pm 0.82^{\mathrm{b}}$ & $4.83 \pm 0.75^{\mathrm{a}}$ & $5.17 \pm 0.75^{\mathrm{a}}$ \\
Fermented smell & $6.17 \pm 0.75^{\mathrm{b}}$ & $6.67 \pm 0.52^{\mathrm{b}}$ & $4.83 \pm 0.75^{\mathrm{a}}$ & $5.00 \pm 0.63^{\mathrm{a}}$ \\
Overall acceptability & $4.50 \pm 0.84^{\mathrm{a}}$ & $6.33 \pm 0.75^{\mathrm{c}}$ & $5.50 \pm 0.55^{\mathrm{b}}$ & $4.33 \pm 0.52^{\mathrm{a}}$ \\
\hline
\end{tabular}

7-point hedonic scale (1: extremely weak, 7: extremely strong).

${ }^{1)}$ Values are means $\pm \mathrm{SD}$.

${ }^{2) a}$ Means in the same row with different letters are significantly different by Duncan's multiple range test $(\mathrm{p}<0.05)$.
한 실험군에서 점수가 각각 $4.50,4.33$ 을 기록하여 상대적으 로 낮은 기호도를 나타냈으며, $50 \%$ 첨가한 실험군이 6.33으 로 가장 높은 기호도 점수를 나타내었다.

이상의 관능평가 결과를 색, 맛, 향, 발효취 강도, 전반적 인 기호도를 통해 종합적으로 고려하면 오미자 착즙 원액에 오미자 발효물 $50 \%$ 첨가한 조건에서 가장 높은 점수를 얻었다. 이로써 오미자 착즙 원액에 오미자 발효물을 $50 \%$ 첨가하여 기호성이 우수하며 고농도 GABA와 probiotic를 함유한 오미자 발효 음료의 제조가 가능하다고 사료되었 다.

\section{요 약}

오미자 열매를 이용하여 기능성물질인 $\mathrm{GABA}$ 를 강화시 킨 오미자 젖산발효음료를 개발하기 위해서 L. plantarum EJ2014에 의한 젖산발효 최적화를 수행하였다. 오미자 열 매 추출액을 젖산 발효시킨 경우 발효 2 일 동안 생균수 $4.0 \times 10^{7} \mathrm{CFU} / \mathrm{mL}$ 수준을 유지하면서 젖산균 증식이 미비하 였지만 영양성분 $\mathrm{YE}$ 와 $\mathrm{MSG}$ 를 함께 첨가한 경우 50배 정도 증가된 $2.2 \times 10^{9} \mathrm{CFU} / \mathrm{mL}$ 생균수를 나타내었다. 특히 젖산발 효 3일 동안에 대조군, $\mathrm{MSG}, \mathrm{YE}$ 를 각각 첨가군에서 초기 $\mathrm{pH}$ 3-4 수준에서 유지되었다. 반면에 $\mathrm{YE}$ 와 $\mathrm{MSG}$ 를 함께 첨가한 발효물은 $\mathrm{pH}$ 가 증가되면서 $\mathrm{pH} 5.0$ 이상을 나타내었 으며, 초기 산도 $1.74 \%$ 에서 발효 3 일에 $0.56 \%$ 수준으로 감소하였다. 오미자 열매 추출물인 대조군과 $2 \% \mathrm{MSG}$ 또는 $0.5 \% \mathrm{YE}$ 만을 첨가한 조건에서는 $\mathrm{GABA}$ 로 소량 전환되는 것으로 나타났다. 반면에 $\mathrm{MSG}$ 와 $\mathrm{YE}$ 를 함께 첨가한 경우 젖산발효 1 일째부터 $\mathrm{GABA}$ 가 생성되면서 3 일째에는 $\mathrm{MSG}$ $2 \%$ 를 거의 소진하는 것으로 나타났으며, HPLC 정량분석 으로 $0.92 \% \mathrm{GABA}$ 생성이 확인되었다. $\mathrm{MSG}$ 와 $\mathrm{YE}$ 함께 첨가한 발효조건에서는 젖산발효 1 일째부터 발효물은 붉 은 색이 퇴색되면서 황색으로 변화하였으며, 발효 초기에 적색을 나타내는 a값이 15.74에서 발효 후에 5.39로 크게 감소하는 것으로 나타났다. 색, 맛, 향 등을 포함한 전반적인 기호도를 나타낸 관능평가에서 오미자 착즙 원액과 발효물 $100 \%$ 인 실험군에서 점수가 각각 $4.50,4.33$ 을 기록하여 상 대적으로 낮은 기호도를 나타낸 반면에 발효물 $50 \%$ 첨가한 실험군이 6.33으로 가장 높은 기호도 점수를 나타내었다. 오미자 열매 추출액에 오미자 발효물을 $50 \%$ 첨가함으로서 기호성이 우수하며 고농도 GABA와 probiotic을 함유한 오 미자 발효음료의 제조가 가능하였다.

\section{감사의 글}

본 결과물은 농림축산식품부의 재원으로 농림수산식품 
기술기획평가원의 기술사업화지원사업의 지원을 받아 연 구되었음(No. 314082-3)

\section{References}

1. Chang SK, Alasalvar C, Shahidi F (2016) Review of dried fruits: phytochemicals, antioxidant efficacies, and health benefits. J Functional Foods, 21, 113-132

2. Hwang ES, Ki KN (2013) Stability of the Anthocyanin pigment extracted from aronia (Aronia melancocarpa). Korean J Food Sci Technol, 45, 416-421

3. Cho SB, Kim HJ, Yoon JI, Chun HS (2003) Kinetic study on the color deterioration of crude anthocyanin extract from Schizandra fruit (Schizandra chinensis fructus). Korean J Food Sci Technol, 35, 23-27

4. Chung KW, Joo YH, Lee DJ (2004) Content and color difference of anthocyanin by different storage periods in seed coats of black soybean [Glycine max (L.) Merr.]. Kor J Int Agric, 16, 196-199

5. Hong JH, Chung HS, Hong U, Youn KS (2002) Storage stability of anthocyanin pigment isolated from a wasted grape peels. Korean J Food Preserv, 9, 327-331

6. Yang HC, Lee JM, Song KB (1982) Anthocyanins in cultured Omija (Schizandrea chinensis Baillon) and its stability. J Korean Agric Chem Soc, 25, 35-43

7. Hong KH, Nam ES, Park SI (2003) Effect of water extract of omija (Schizandra chinensis) on growth of yoghurt starter. Korean J Food Sci Ani Resour, 23, 333-341

8. Park SS (2013) Biochemical characterization and biological activity of Schizandra chinensis (Turcz.) Baill fermented by Lactobacillus fermentum MieW L1106. MS thesis, Dong-A University, Korea, 1-2

9. Molokovskii DS, Davydov VV, Tiulenev VV (1989) The action of adaptogenic plant preparations in experimental alloxan diabetes. Probi Endokrinol, 35, 82-87

10. Zhu M, Lin KF, Yeung RY, Li RC (1999) Evaluation of the protective effects of Schisandra chinensis on phase I drug metabolism using a CCl4 intoxication model. J Ethnopharmacol, 67, 61-68

11. Ingram M (1975) The lactic acid bacteria: a broad view. In Lactic acid bacteria in Beverages and food. Academic Press, London, UK, p 1-13
12. Sanders ME (1998) Overview of functional foods: emphasis on probiotic bacteria. Int Dairy Journal, 8, 341-347

13. Metchnikoff E (1908) The prolongation of life. C.P. Putanama's sons. New York, USA, 161

14. Miral BK, Steinkraus KH (1974) Growth of Lactic acid bacteria in soy milks. J Food Sci, 39, 1018-1022

15. Fleming HP, Mcfeeters RF, Thompson RL, Sander DC (1983) Storage stability of vegetable fermented with $\mathrm{pH}$ control. J Food Sci, 48, 975-981

16. Cagno RD, Coda R, Angelis MD, Gobbetti M (2013) Exploitation of vegetables and fruits through lactic acid fermentation. Food Microbiol, 33, 1-10

17. Mody I, Dekoninck Y, Otis TS, Soltesz I (1994) Bringing the cleft at GABA synapses in the brain. Trends Neurosci, $17,517-525$

18. Bown AW, Shelp BJ (1997) The metabolism and function of $x$-aminobutyric acid. Plant Physiol, 115, 1-5

19. Diana M, Quilez J, Rafecas M (2014) Gamma-aminobutyric acid as a bioactive compound in foods: a review. J Functional Foods, 10, 407-420

20. Oh SH, Oh CH (2003) Brown rice extracts with enhanced levels of GABA stimulate immune cells. Food Sci Biotechnol, 12, 248-252

21. Luchsinger WW, Cornesky RA (1962) Reducing power by the dinitrosalicylic acid method. Anal Biochem, 4, 346-347

22. Mocan A, Crisan G, Vlase L, Crisan O, Vodnar DC, Raita O, Gheldiu AM, Toiu A, Oprean R, Tilea I (2014) Comparative studies on polyphenolic composition, antioxidant and antimicrobial activities of Schisandra chinensis leaves and fruits. Molecules, 19, 15162-15179

23. Kim YS, Kim YS, Kim SY, Whang JH, Suh HJ (2008) Application of omija (Schisandra chinensis) and plum (Prunus mume) extracts for the improvement of kimchi quality. Food Control, 19, 662-669

24. Drinan DF, Robin S, Cogan TM (1976) Citric acid metabolism in hetero-and homo-fermentative lactic acid bacteria. Appl Environ Microbiol, 31, 481-486

25. Feehily C, Karatzas, KA (2013) Role of glutamate metabolism in bacterial responses towards acid and other stresses. J Appl Microbiol, 114, 11-24 